\title{
Flood Rescue Boat as One of the Alternatives in Indonesia Waterways
}

\author{
Ede Mehta Wardhana, ${ }^{\text {a* }}$ Meitha Soetardjo, ${ }^{\mathrm{b}}$ and A. Bisri, ${ }^{\mathrm{c}}$ \\ a) Department of Marine Engineering, Institut Teknologi Sepuluh Nopember, Indonesia \\ ${ }^{b)}$ Laboratory for Hydrodynamics Technology, BTH Surabaya - Indonesia \\ ${ }^{c)}$ Center of Technology for Maritime Industrial Engineering, PTRIM Surabaya - Indonesia \\ *Corresponding author: meithasoetardjo@gmail.com
}

\section{Paper History}

Received: 21-July-2019

Received in revised form: 28-November-2019

Accepted: 30-November-2019

\begin{abstract}
Flooding is the most frequent disaster that hit Indonesia, especially in big cities with poor urban planning. Infrastructure damage has occurred, the fatalities which are likely to occur, both during floods and after floods. So far, the fatalities caused by floods are very difficult to control and even tend to increase. This condition is getting worse with the lack of facilities that support the evacuation process of flood victims. The aim of the study was to design a lifeboat that was able to evacuate flood victims and be able to overcome other problems that might arise when the evacuation process runs more efficiently. By collecting data from several agencies related to flood mitigation problems, interviews with experts, as well as several other references, it is hoped that relevant data can be collected, which can provide solutions to the problems faced. The stages of the research included the creation of concepts and the design of a hull shape that was adjusted for a flood rescue boat, a boat with high stability. By using of the Maxsurf V.8.5 and Hydromax V.8.5 program, it is expected that the design process and calculation of boat stability can be done more quickly and accurately. The results of research for several areas affected by floods, the existence of a rescue boat as a means to evacuate victims is urgently needed. So that the provision of a multifunctional flood rescue boat is the perfect solution to overcome this problem. To carry out this function, the stability of the rescue boat flood is one of the factors that must be considered so that the evacuation process can be carried out safely.
\end{abstract}

KEY WORDS: Flood rescue boat, Maxsurf V.8.5, Hydromax V.8.5, Stability.

\subsection{INTRODUCTION}

For many years, a metropolitan city in Indonesia has many disasters. From earthquake, tsunami, flood and other things that people in the area of disasters lost various things, including their lives. There are various types of disasters that could occur in this case, one of those is the disaster that could be predicted and one that is happening periodically. Based on the type, Indonesian people and the government could do a preventive action to least minimize the damage that might happen in the area. Apparently, this preventive action still not as effective as people hoped. There are various preventive actions to ensure that disasters not happening, but people could forget that the first-aid action is as important as preventive action to minimize the damage.

Based of the observations, it shows that the challenge of the periodical disaster (like flood) is the responsiveness of the first-air help. Looking at flooding in Indonesia, especially in Jakarta around the year 2000, it is seen that the current drainage system still needs more improvement. A heavy rain that goes non-stop makes the volume of the water from 13 rivers from around Jakarta-Bogor-Puncak-Cianjur and with addition of the high tide makes almost $60 \%$ of Jakarta to be submerged with flood. This flood has water with a height reach $5 \mathrm{~m}$ on several locations. Damage that happens in this state is astronomical. This is happened due to many reasons, such as not enough personnel and not enough facilities.

Based on those experiences, the idea to design a flood rescue boat as one of the alternatives to minimize the damage from flooding came. This boat will be equipped with various facilities needed including the first aid help for the victim of the flooding. The main purpose of this boat is to evacuate the people who are trapped in a tight street, alley or even small pathway around their 
homes/location. This flood rescue boat also equipped with a fire extinguisher. We are hopeful that the realization of this boat could minimize the life victim and material losses.

\section{Research Main Point}

This research is focusing on designing the hull from the flooding rescue boat. Those design needs to have a high stability and needs to be suitable with the environment and condition at the site the boat will be operated. In order to gain a better calculation in the stability, each factor that correlated with stability will be calculated using a CFD program. After the design of the hull is finished, the design will be added until the General Arrangement of the ships. This General Arrangement of the boat is to ensure that based on the design, this boat could move and operated around the alley and it could be operated with a flood height around $0.5 \mathrm{~m}$ minimum. This flood rescue boat is focused in area in Jakarta with the height of the building around 8 meter minimum ( 2 stores building) with the minimum of flood height is around 2 meters.

The design of this boat construction is made with class register of the Lloyd Register. The Fire classification that is used the class a classification (Fuel will leave carbon and ashes when burned). The firefighting tools will be used a portable pump, and we will ignore the influence of the dynamic movement of the pump to the boat motion.

\subsection{DESIGN REQUIREMENT}

\subsection{Boat Design}

Based on [1] by Gerard Dijkstra, the methodical approach used for designing the boat is not much different from designing ships or other marine vessel. In general, there are 4 design process, which are:

1. Make and state the design requirement

2. Formulating the design concept (design problem-solving)

3. Determination of ship design characteristic

4. Evaluate the solution

Steps 2-4 will be evaluated and revised over and over until the requirement stated in step 1 is fulfilled. In special cases, which there is no problem solving to fulfilled the regulation or there are some issues for the requirement, then the design requirement needs to be recheck and revised until the required terms could be tolerated.

\subsection{Planned Design}

Based on the design process, there are several things that we need to set up for our design:

a) Capacity

This requirement is inculding deadweight, cargo load, cargo capacity, amount of crew and estimated passenger and others. This requirement will be correlated with the setup and basic design of the space area, accomodation for the passenger, and placement of safety equipment. Based on the survey of Search and Rescue Team in surabaya, for boat with the operational in the main city land, it needs to be able to carry passenger around 8-10 people with equipment such as life jacket, first aid kit, fire extinguisher and paddle in it. However, based on Australian Emergency Manuals Series (AEMS) the boat also needs several equipment in it. Those equipment is shown in the Table 1 .

Table 1: Equipments in the ship

\begin{tabular}{|c|c|}
\hline EQUIPMENT & QUANTITY \\
\hline \multicolumn{2}{|l|}{ Basic Equipment } \\
\hline $\begin{array}{l}\text { Personal Floatation Devices(life jackets } \\
\text { in accordance with AS1512) }\end{array}$ & $\begin{array}{l}1 \text { for every } \\
\text { person up to the } \\
\text { anticipated } \\
\text { loading }\end{array}$ \\
\hline $\begin{array}{l}\text { Oars with rowlocks (to match) (or) } \\
\text { Paddles }\end{array}$ & 1 pair of each \\
\hline \multicolumn{2}{|l|}{$\begin{array}{l}\text { Anchors (complete with chain and line } \\
\text { attached): }\end{array}$} \\
\hline Danforth or reef anchor & 1 \\
\hline $\begin{array}{l}\text { Galvanised metal bucket or bailer, (min } 9 \\
\text { liter, fitted with lanyard of at least } 2 \mathrm{~m} \text { ) }\end{array}$ & 1 \\
\hline First aid kit (waterproof) & 1 \\
\hline Approved fire extinguisher & 1 \\
\hline Torch (waterproof with spare batteries) & 1 \\
\hline Spotlight (complete with batteries) & 1 \\
\hline \multicolumn{2}{|l|}{ Drinking water } \\
\hline Bolt cutters & 1 \\
\hline Wire cutters & 1 \\
\hline Axe/hatchet & 1 \\
\hline Bow and stern lines (10m x 12mm) & 1 \\
\hline Boat hook & 1 \\
\hline Towing bridle & 1 \\
\hline Knife (with sheath) & 1 \\
\hline Fuel tank (complete with fuel lines) & 2 \\
\hline Propeller & 2 spare \\
\hline \multicolumn{2}{|l|}{ De-watering spray (WD 40 or similar) } \\
\hline Ropes & as required \\
\hline \multicolumn{2}{|l|}{ Split pins } \\
\hline \multicolumn{2}{|l|}{ Shear pins } \\
\hline \multicolumn{2}{|l|}{ Spare bungs } \\
\hline \multicolumn{2}{|l|}{ Tool kit (complete) } \\
\hline \multicolumn{2}{|l|}{ Safety chain (motor to transom) } \\
\hline \multicolumn{2}{|l|}{ Radio (complete with Antenna) } \\
\hline \multicolumn{2}{|l|}{ Navigation lights } \\
\hline \multicolumn{2}{|l|}{ Maps, charts and compass } \\
\hline \multicolumn{2}{|l|}{ Special Equipment } \\
\hline \multicolumn{2}{|l|}{ Stretcher } \\
\hline Space blankets & \\
\hline
\end{tabular}

b) Principal Dimension

The main point of this boat is designed to be able to carry 9 person in it. Based on the calculation, the principal dimension of this boat is : $\mathrm{Lpp}=4.87 \mathrm{~m}, \mathrm{~B}=1.87 \mathrm{~m}, \mathrm{Lpp}=0.17 \mathrm{~m}$

c) Hull Shape

The shape of hull is based on the area of the boat operation. Because the depth of the water from the flood could be too shallow, then the hull is shaped into a flat bottom. This is done with te pirpose to reduce the draft dimension. With the same discplacement and length, bottom flat tend to have a smaller draft rather than $\mathrm{V}$ shape hull or catamaran. Other than that, bottom flat also make the evacuation process smoother. 
d) Pump Requirement

Head Pump is the height or space needed to be achieved by a pressurized fluid based on the pump pressure and losses in the system itself. Head will be calculated with the formula:

$$
\begin{aligned}
& h=\frac{p \times 10.197}{S G}(m) \\
& \mathrm{Q} \quad=449 \times \mathrm{V} \times \mathrm{A} \\
& \text { BHP }=\frac{\text { QxhxSG(SpesificGrafity)}}{3960 \times \text { eff }}(H P)
\end{aligned}
$$

e) General Arrangement

General arrangement of the ship will be designed based on the literature review and the experiment from previous studies. The design of the general arrangement will be measured and will be compared with existing data. In order to be designed perfectly, there is information to obtain:

- Ships Principal Dimension

- Crew Section: Based on the field survey in Surabaya, there are two type of crew in the rescue boat. Those crew main job are:

- As the navigator of the boat

- As the evacuator for the victim

However, in the reality both of these crew needs to be able to do both of the tasks. The crew needs to be a multifunction crew.

- Main Propulsion: Based on the field survey in Surabaya, the engine used in the rescue boat has 2 types. One that used with a $15 \mathrm{HP}$ engine or one with the $25 \mathrm{HP}$ engine. In the field itself, it is estimated to use the $15 \mathrm{HP}$ engine due to its efficiency when rescuing people. When the evacuation process is started, the boat needs to have a relatively low speed to help people went overboard the rescue boat.

f) Deadweight Calculation

In order to calculate Deadweight (DWT), there are 3 conditions in this rescue boat. Those conditions are: Rescue, Supply and Firefighting. DWT itself is calculated based on several things, those are:

- Weight of Fuel oil M/E

- Weight of Fresh Water

- Weight of Pump \& its equipment

- Weight of Food supply

- Weight of the Crew \& its belonging

- Weight of residual (Emergency factor)

- Weight of Net Tonnage (Weight of the estimated victim)

- Weight of rescue equipment

g) Quick Riling System and Ladder Platform

In principle, Quick riling system has the same function with the bollard on ships. However in this case, quick riling system is used to binding one boat to another. Those united / bonded boat has a different purpose. One of those purposes is used as the bridge for other people to cross in the flooding condition.

Ladder Platform is also used as the main tool to help the people get onboard of the rescue boat in evacuation process. The ladder is located in front of the boat. This placement of ladder is set on the front in order to keep the stability of the boat in a good region.

\subsection{DESIGN CALCULATION \& ANALYSIS}

\subsection{Calculation}

For DWT in this boat, there are 3 stage of the operation mode. Those modes are:

- Rescue condition

- Distribute \& Supply condition

- Fire fighting condition mode

From that entire operation mode, the heaviest condition is on the evacuation mode. Because of this reason, the calculation of DWT will be estimated on evacuation mode with this calculation:

a. Weight of M/E Fuel (Wfo)

$$
\begin{aligned}
\text { Wfo } & =80 \% \times \text { BHP } \times 0.17 \times \text { days } \\
\text { Wfo } & =80 \% \times 15 \times 0.17 \times 1 / 8 \\
& =0.255 \mathrm{~kg} \times 2 \text { Engine } \\
& =0.51 \mathrm{~kg}
\end{aligned}
$$

b. Weight of Crew (Wcp)

$\mathrm{Wcp}=\mathrm{Ze} \times \mathrm{Ccp}$

$\mathrm{Wcp}=2 \times 65 \mathrm{~kg}$

$$
=130 \mathrm{~kg}
$$

c. Weight of the Cargo - victim of Flood (Wpc)

$$
\begin{aligned}
\mathrm{Wpc} & =\mathrm{Ze} \times \mathrm{Cpc} \\
\mathrm{Wpc} & =9 \times 65 \mathrm{~kg} \\
& =585 \mathrm{~kg}
\end{aligned}
$$

d. Weight of the equipment

W.Peral $=$ W. Life Jacket + W. First aid + W. row tools + $W$. main engine $+W$. platform

$$
\begin{aligned}
& \text { W. Life jacket }=(\text { Crew }+ \text { Victim }) \times \text { W Life jacket } \\
& =11 \times 2 \mathrm{~kg} \\
& =22 \mathrm{~kg} \\
& \text { W. Fisrt Aid Kid = amount. } \mathrm{x} \text { W First aid } \\
& =9 \times 3 \mathrm{~kg} \\
& =27 \mathrm{~kg} \\
& \text { W. Row tools = amount. } \mathrm{x} \text { W row } \\
& =2 \times 5 \mathrm{~kg} \\
& =10 \mathrm{~kg} \\
& \mathrm{~W} \text {. Main Engine = amount. } \mathrm{x} \mathrm{W} \text {. main engine } \\
& =1 \times 50 \mathrm{~kg} \\
& =50 \mathrm{~kg} \\
& \text { W. platform = amount. } \mathrm{x} \text { platform } \\
& =1 \times 7 \mathrm{~kg} \\
& =7 \mathrm{~kg} \\
& \mathrm{~W} \text {. fire extinguisher }=\text { amount. } \mathrm{x} \text { fire extinguisher } \\
& =1 \times 5 \mathrm{~kg} \\
& =5 \mathrm{~kg} \\
& \text { W. equipment }=22 \mathrm{~kg}+27 \mathrm{~kg}+10 \mathrm{~kg}+50 \mathrm{~kg}+ \\
& 7 \mathrm{~kg}+5 \mathrm{~kg} \\
& =121 \mathrm{~kg}
\end{aligned}
$$

For the LWT calculation and planned design, it will be calculated using another sister ship based on the same type with 
the planned boat. The data about sister ship is shown on Table. 2

Table 2: Rescue boat sister ship

\begin{tabular}{|c|c|c|c|c|c|c|c|}
\hline No. & $\begin{array}{c}\text { LOA } \\
(\mathrm{m})\end{array}$ & $\begin{array}{c}\mathrm{B} \\
(\mathrm{m})\end{array}$ & $\begin{array}{c}\mathrm{H} \\
(\mathrm{m})\end{array}$ & $\begin{array}{c}\mathrm{T} \\
(\mathrm{m})\end{array}$ & $\begin{array}{c}\text { LWT } \\
\text { (ton) }\end{array}$ & Cb & $\begin{array}{c}\text { Displ } \\
\text { (ton) }\end{array}$ \\
\hline 1 & 4.87 & 1.87 & 0.53 & 0.17 & 0.297 & - & 1.184 \\
\hline
\end{tabular}

\begin{tabular}{|c|c|}
\hline$\Delta(\mathrm{p})$ & $=1.184$ ton \\
\hline LWT(p) & $=0.297 \mathrm{ton}$ \\
\hline $\operatorname{DWT}(\mathrm{p})$ & $\begin{array}{l}=\Delta-\text { LWT } \\
=1.184-0.297 \\
=0.887 \text { ton } \\
=887 \mathrm{~kg}\end{array}$ \\
\hline
\end{tabular}

$(\mathrm{LWT} / \Delta) 100 \%=(0.297 / 1.184) 100 \%$

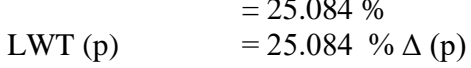

$\Delta(\mathrm{p})$

$=\left(\frac{100}{25.084}\right)$ LWT $(\mathrm{p})$

$\operatorname{LWT}(\mathrm{p})+\operatorname{DWT}(\mathrm{p}) \quad=\Delta(\mathrm{p})$

$\operatorname{LWT}(\mathrm{p})+\operatorname{DWT}(\mathrm{p}) \quad=\left(\frac{100}{25.084}\right) \operatorname{LWT}(\mathrm{p})$

$\operatorname{DWT}(\mathrm{p})$

$=\left(\frac{100}{25.084}-1\right) \operatorname{LWT}(\mathrm{p})$

$\operatorname{LWT}(\mathrm{p})$

$$
=\frac{D W T(p)}{\frac{100}{25.084}-1}
$$

In conclusion

LWT (planned)

$$
\begin{aligned}
= & \frac{D W T \text { (planned })}{\frac{100}{25.084}-1} \\
= & \frac{836.51 \mathrm{~kg}}{\frac{100}{25.084}-1} \\
= & 280 \mathrm{~kg}
\end{aligned}
$$

After the value of LWT \& DWT is calculated and planned, then the value of weight displacement could be obtained using:

$$
\begin{aligned}
\text { Displacement } & =\mathrm{DWT}+\mathrm{LWT} \\
& =836.51 \mathrm{~kg}+280 \mathrm{~kg} \\
& =1116.51 \mathrm{~kg}
\end{aligned}
$$

Displacement used in this design is $1150 \mathrm{~kg}$. To make a new principal dimension, data from various sister ships in Table 3 is used.

Table 3: Recap of rescue boat sister ship

\begin{tabular}{|c|c|c|c|c|c|c|}
\hline No. & LOA & B & H & T & Cb & Displ. \\
\hline 1 & 4.87 & 1.87 & 0.53 & 0.17 & - & 1.18 \\
\hline 2 & 4.85 & 1.83 & 0.5 & 0.18 & 0.80 & 1.31 \\
\hline 3 & 4.20 & 1.85 & 0.8 & 0.2 & 0.80 & 1.35 \\
\hline 4 & 4.50 & 2.5 & 0.55 & 0.23 & 0.84 & 1.50 \\
\hline
\end{tabular}

\section{Length (Designed)}

Usign equation of the ship length and the function of the ship desplacement, $\mathrm{L}=f(\Delta)$

\begin{tabular}{|c|c|}
\hline \multicolumn{2}{|c|}{ Displ - L } \\
\hline \multicolumn{2}{|c|}{$\mathrm{y}=\mathrm{m} . \mathrm{x}+\mathrm{b}$} \\
\hline $\mathrm{m}=$ & 0.3897 \\
\hline $\mathrm{b}=$ & 4.3470 \\
\hline $\mathrm{y}=$ & $0.3897 \mathrm{X}+4.3470$ \\
\hline $\mathrm{L}$ for Displacement of $1150 \mathrm{~kg}$ \\
\hline $\mathrm{L}=$ & 4.795108999 \\
\hline
\end{tabular}

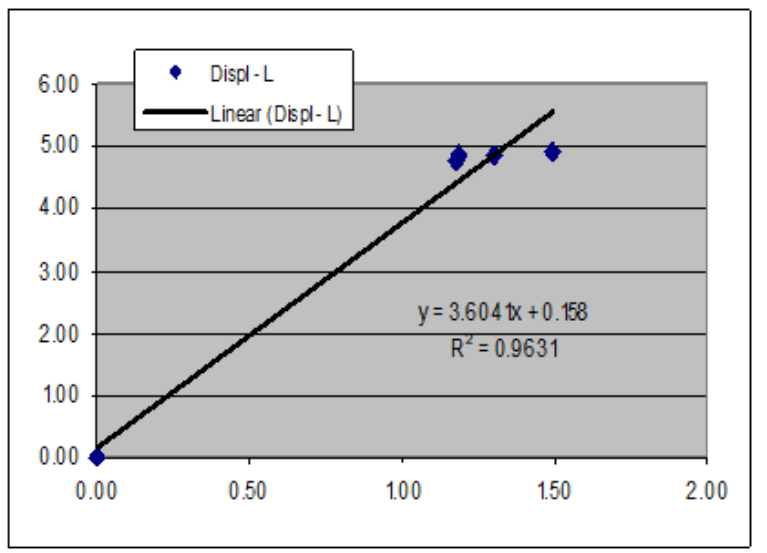

Figure 1: Length of Regression Displ - L

Based on the graph in Figure 1, it could used the formula:

$$
\begin{array}{ll}
\text { Length }(\mathrm{L}) & =0.3897(\Delta)+4.3470 \\
\text { So the L } & =4.795108999 \mathrm{~m} \\
\text { L used } & =\mathbf{4 . 8} \mathbf{~ m}
\end{array}
$$

Using the same principal, the value of $\mathrm{B}, \mathrm{T}, \mathrm{H}$ will be used the regression shown in Figure 2-4. Function of displacement, B $=f(\Delta)$.

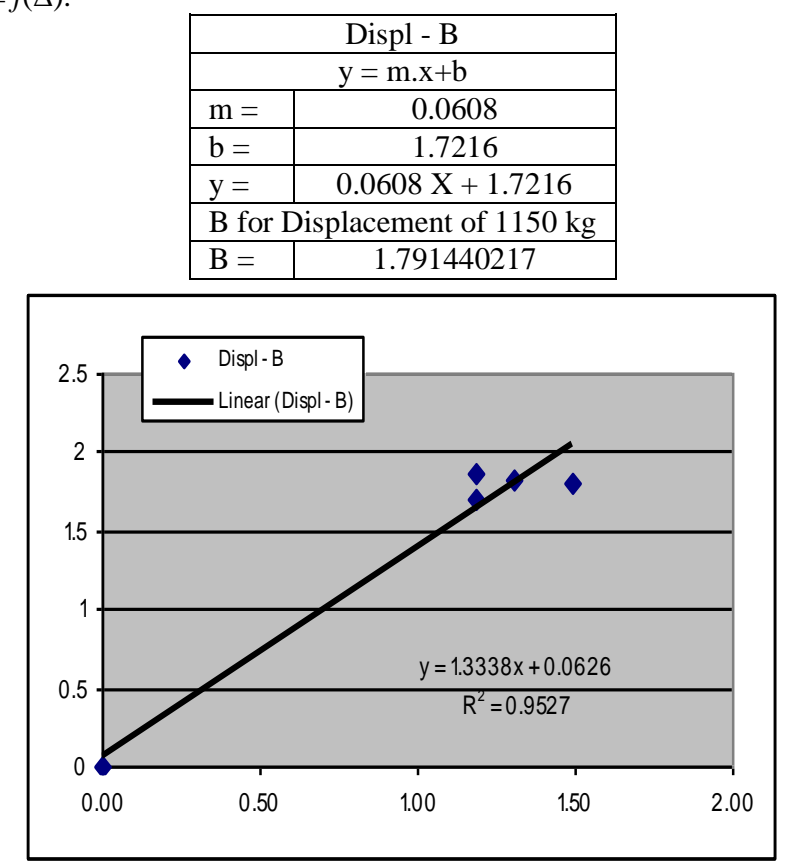

Figure 2: Length of Regression Displ - B 


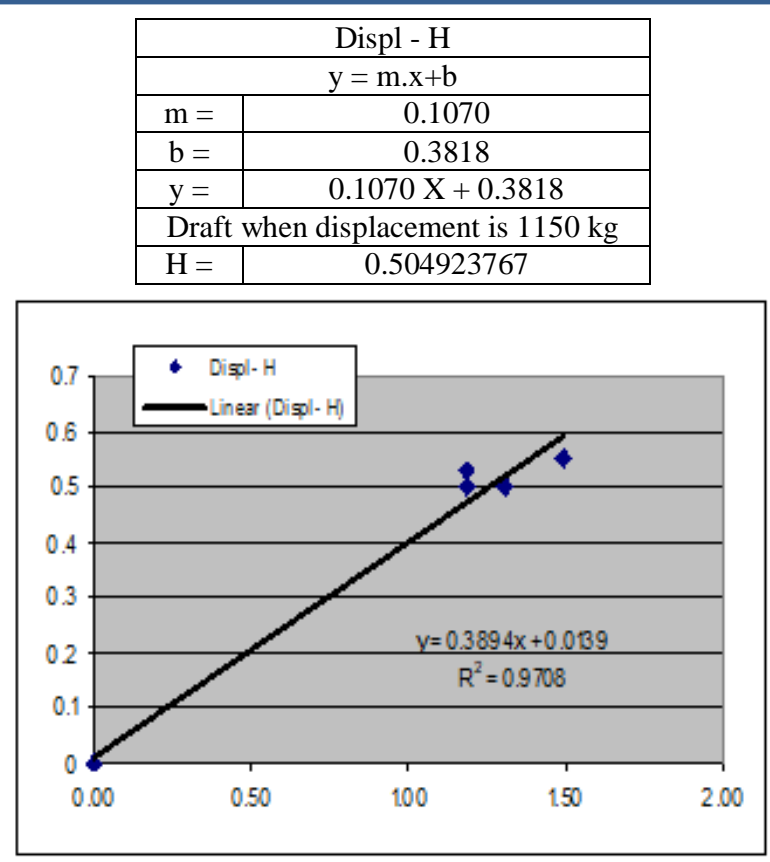

Figure 3: Length of Regression Displ - H

\begin{tabular}{|c|c|}
\hline \multicolumn{2}{|c|}{ Displ - T } \\
\hline \multicolumn{2}{|c|}{$\mathrm{y}=\mathrm{m} . \mathrm{x}+\mathrm{b}$} \\
\hline $\mathrm{m}=$ & 0.0690 \\
\hline $\mathrm{b}=$ & 0.0962 \\
\hline $\mathrm{y}=$ & $0.0690 \mathrm{X}+0.0962$ \\
\hline Height when displacement is $1150 \mathrm{~kg}$ \\
\hline $\mathrm{T}=$ & 0.175534693 \\
\hline
\end{tabular}

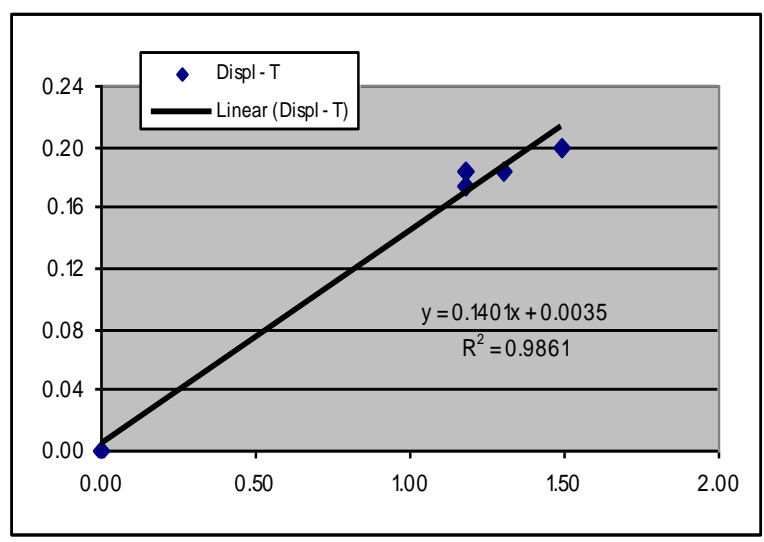

Figure 4: Length of Regression Displ-T

Based on the graph \& table, the value of principal dimension are:

$$
\begin{aligned}
\text { Loa } & =4.8 \mathrm{~m} \\
\mathrm{~B} & =1.8 \mathrm{~m} \\
\mathrm{H} & =0.5 \mathrm{~m} \\
\mathrm{~T} & =0.175 \mathrm{~m}
\end{aligned}
$$

After the principal dimension based from the linear regression method for the rescue boat are obtained, then the lines plane will be made using our Maxsurf Professional V 8.5 software. This is made based on the the designed displacement. The making of linesplan is for the basis of the boat general arrangement for rescue boat. The maxsurf programme will also give us the estimated stability calculation from our boat.

From our displacement results and design in Maxurft, it is estimated that the calculation of displacement is around 1152.1 $\mathrm{kg}$. It is in par with our planned displacement $(1150 \mathrm{~kg})$. Because there is a difference, then the correction of the displacement will be made using the formula of :

$$
\begin{aligned}
\Delta & =\{[\Delta(\text { Maxsurf })-\Delta(\text { planned })] / \Delta(\text { Maxsurf })\} \times 100 \% \\
& =\{[1152.156 \mathrm{~kg}-1150] / 1152.156 \mathrm{~kg}\} \times 100 \% \\
& =0.187 \% .
\end{aligned}
$$

With that percentage, the correction of displacement is met with the requirement. Information from our Maxsurf is the data of the boat Hydrostatic. This information could be seen in Table 4 and Table 5.

Table 4: Hydrostatic of the rescue boat

\begin{tabular}{|l|l|l|l|}
\hline Displacement & $\begin{array}{l}1152.156 \\
\mathrm{~kg}\end{array}$ & $\begin{array}{l}\text { LCF from zero } \\
\text { pt }\end{array}$ & $-2.514 \mathrm{~m}$ \\
\hline Draft & $0.175 \mathrm{~m}$ & KB & $0.09 \mathrm{~m}$ \\
\hline Lwl & $4.315 \mathrm{~m}$ & KG & $135.4 \mathrm{~m}$ \\
\hline Beam wl & $1.735 \mathrm{~m}$ & BMt & $1.596 \mathrm{~m}$ \\
\hline WSA & $8.647 \mathrm{~m}^{\wedge} 2$ & BMl & $9.1 \mathrm{~m}$ \\
\hline $\begin{array}{l}\text { Max cross sect } \\
\text { area }\end{array}$ & $0.301 \mathrm{~m}^{\wedge} 2$ & GMt & $-133.713 \mathrm{~m}$ \\
\hline Water plane area & $7.249 \mathrm{~m}^{\wedge} 2$ & GMI & $-126.21 \mathrm{~m}$ \\
\hline Cp & 0.889 & KMt & $1.687 \mathrm{~m}$ \\
\hline Cb & 0.879 & KMl & $9.19 \mathrm{~m}$ \\
\hline Cm & 0.99 & Immersion $($ TPc) & $\begin{array}{l}0.072 \\
\text { tonne } / \mathrm{cm}\end{array}$ \\
\hline Cwp & 0.968 & MTc & $\begin{array}{l}-0.343 \\
\text { tonne.m }\end{array}$ \\
\hline LCB from zero pt & $-2.62 \mathrm{~m}$ & $\begin{array}{l}\text { RM at 1deg }= \\
\text { GMt.Disp. } \sin (\mathbf{1})\end{array}$ & $\begin{array}{l}34.488 \\
\text { kg.m }\end{array}$ \\
\hline
\end{tabular}

Table 5: Hydrostatic of the rescue boat using hydromax

\begin{tabular}{|c|l|l|}
\hline 1 & Draft Amidsh. mm & 32.328 \\
\hline 2 & Displacement kg & 192 \\
\hline 3 & Heel to Starboard degrees & 0 \\
\hline 4 & Draft at FP mm & 45.717 \\
\hline 5 & Draft at AP mm & 18.938 \\
\hline 6 & Draft at LCF mm & 31.621 \\
\hline 7 & Trim (+ve bow down $) \mathrm{mm}$ & 26.779 \\
\hline 8 & WL Length mm & 3895.558 \\
\hline 9 & WL Beam mm & 1708.928 \\
\hline 10 & Wetted Area $\mathrm{mm}^{\wedge} 2$ & 6640831.094 \\
\hline 11 & Waterpl. Area $\mathrm{mm}^{\wedge}$ & 6415021.264 \\
\hline 12 & Prismatic Coeff. & 0.709 \\
\hline 13 & Block Coeff. & 0.707 \\
\hline 14 & Midship Area Coeff. & 0.998 \\
\hline 15 & Waterpl. Area Coeff. & 0.964 \\
\hline 16 & LCB to Amidsh. mm & 40.414 Fwd \\
\hline 17 & LCF to Amidsh. mm & 113.852 Aft \\
\hline 18 & KB mm & 16.725 \\
\hline 19 & KG mm & 135.400 \\
\hline 20 & BMt mm & 8363.382 \\
\hline 21 & BML mm & 39892.029 \\
\hline 22 & GMt mm & 8244.704 \\
\hline 23 & GML mm & 39773.352 \\
\hline
\end{tabular}




\begin{tabular}{|l|l|l|}
\hline 24 & KMt mm & 8380.107 \\
\hline 25 & KML mm & 39908.754 \\
\hline 26 & Immersion (TPc) tonne/cm & 0.064 \\
\hline 27 & MTc tonne.m & 0.018 \\
\hline 28 & RM at 1deg = GMt.Disp.sin(1) kg.mm & 27629.341 \\
\hline
\end{tabular}

Based on IMO, the height of the point of $\mathrm{MG}$ is $0.15 \mathrm{~m}$ (minimum):

$$
\mathrm{MG}=\mathrm{KB}+\mathrm{MB}-\mathrm{KG}
$$

From Hydromax obtained data as follows:

$$
\begin{aligned}
\mathrm{KB} & =0.0167 \mathrm{~m} \\
\mathrm{MB} & =8.363 \mathrm{~m} \\
\mathrm{KG} & =0.135 \mathrm{~m} \\
\mathrm{MG} & =0.0167+8.363-0.135 \\
\mathrm{MG} & =8.2447 \mathrm{~m} \text { (comply) }
\end{aligned}
$$

\subsection{Pump Calculation and Arrangement}

In the pump firefighting, the firefighting team used several types of the pump. The general pump function is to transfer the liquid from one place to another place. In our firefighting pump, our primary need is to give it enough pressure to transfer the water on a certain height $\&$ length. In order to install the pump in our boat, we will use the basic standard from Indonesia fire fighting Department Service:

1. Maximum Capacity of the water is 3400 liter

2. NPSH of the pump is $1.5 \mathrm{~m}$ from the land surface

3. Minimum pressure is 4 bar and maximum pressure is around 8 bar

4. Inlet/outlet pipes is around 1.5-4 inch

5. Nozzle diameter is $1.5 \mathrm{inch}$

6. Fire Monitor (System for water spraying is not using a hose) is made from metal

The calculation of pump needed is:

a. Planned height based on specific gravity, height and pressure

$$
h=\frac{\text { px10.197 }}{\text { SpesificGrafity }}(m)
$$

Where;

$$
\mathrm{p} \text { (Pressure) }=5 \mathrm{bar}
$$

SG (Specific Graffiti) $=1$ (for freshwater $)$

$$
\begin{aligned}
& h=\frac{5 \times 10.197}{1}(m) \\
& h=50.985 m
\end{aligned}
$$

b. Capacity

$$
\mathrm{Q}=449 \times \mathrm{V} \times \mathrm{A}
$$

Where;

$$
\begin{aligned}
& \mathrm{V}=2 \mathrm{~m} / \mathrm{s}=6.56 \mathrm{ft} / \mathrm{s} \\
& \mathrm{A}\left(\text { pipe area) }=1 / 4 \pi \mathrm{D}^{2}\right. \\
& \mathrm{A}=1 / 4 \times 3.14 \times 0.25^{2}=0.049 \mathrm{ft}^{2} \\
& \mathrm{Q}=449 \times 6.56 \times 0.049 \\
& \mathrm{Q}=144.327 \mathrm{GPM} \text { (Gallon per minute) } \\
& \mathrm{Q}=656.123 \mathrm{LPM} \text { (Liter per Minute) }
\end{aligned}
$$

c. Pump Power Needed

$$
B H P=\frac{Q x h x S G(\text { SpesificGrafity })}{3960 x e f f}(H P)
$$

Where;

$\mathrm{Q}=144.327$ gallons/minute.

$\mathrm{H}=50.985 \mathrm{~m}=167.27$ feet .

$\mathrm{SG}=1$

$$
\begin{aligned}
& E f f=80 \%=0.8 \\
& B H P=\frac{144.327 \times 167.27 \times S G(\text { SpesificGrafity })}{3960 x 80 \%}(H P) \\
& B H P=5(H P) \\
& \text { power }=3.73 \mathrm{~kW}
\end{aligned}
$$

Based on this data, we could make the pump operational procedure for pump calculation. This is could be seen on Table 6 and Figure 2 that shows the correlation between pump capacity and its head with the power from engine is fixed (assumption).

Table 6: Head, Pressure and Capacity on fixed power pump

\begin{tabular}{|c|c|c|c|c|}
\hline \multicolumn{2}{|c|}{ Head } & (Pressure $)$ & \multicolumn{2}{c|}{ Q } \\
\hline $\mathrm{m}$ & feet & Bar & GPM & LPM \\
\hline 60 & 196.85 & 5.88 & 78.38 & 355.82 \\
\hline 55 & 180.45 & 5.39 & 85.50 & 388.17 \\
\hline 50 & 164.04 & 4.90 & 94.05 & 426.99 \\
\hline 45 & 147.64 & 4.41 & 104.50 & 474.43 \\
\hline 40 & 131.23 & 3.92 & 117.56 & 533.73 \\
\hline 35 & 114.83 & 3.43 & 134.36 & 609.98 \\
\hline 30 & 98.43 & 2.94 & 156.75 & 711.65 \\
\hline 25 & 82.02 & 2.45 & 188.10 & 853.97 \\
\hline 20 & 65.62 & 1.96 & 235.13 & 1067.47 \\
\hline 15 & 49.21 & 1.47 & 313.50 & 1423.29 \\
\hline 10 & 32.81 & 0.98 & 470.25 & 2134.94 \\
\hline
\end{tabular}
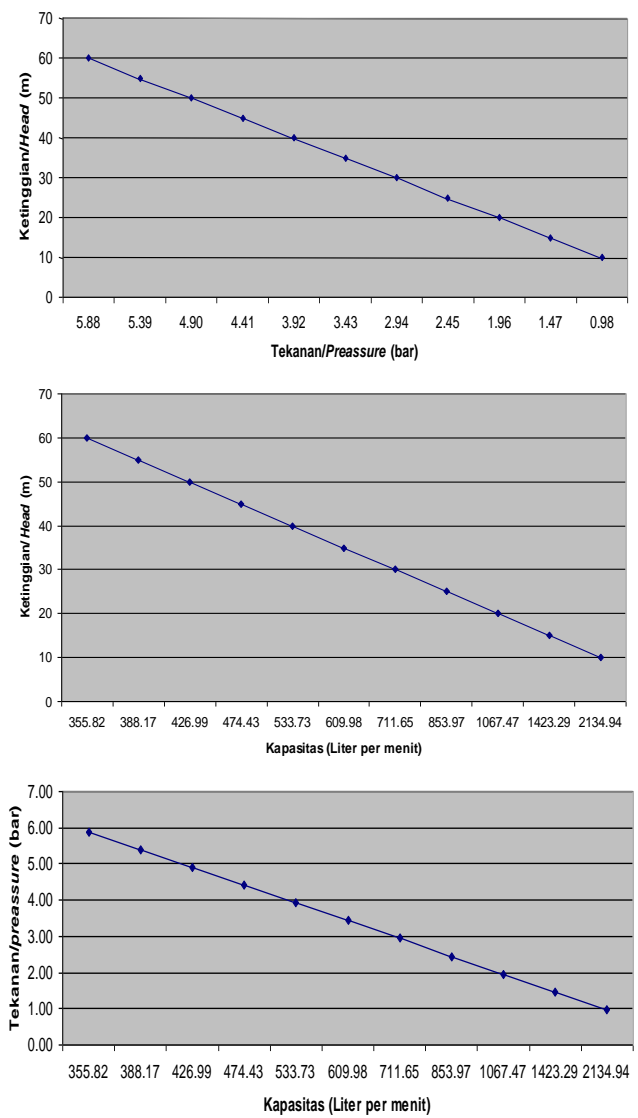

Figure 5: Graph of the Head, Pressure and Capacity on fixed power pump 
Based on this important, we could install the pump with TS6/6

Ultra Compact. The data for the pump is shown below:
Model
TS 6/6 Ultra-Compact
Pump Capacity
$600 \mathrm{~L} / \mathrm{min}$ at 6 bar
Pump Engine
Briggs \& Stratton 1 cyl, petrol, air cooled
Power 4.7 HP
$\operatorname{Dim}(\mathbf{L x W x H})$
$745 \times 440 \times 590 \mathrm{~mm}$
Weight
$94 \mathrm{~kg}$ (with electric starter)

\subsection{Engine selection and Calculation of Various Mode}

In this rescue boat, since the length of the boat is no more than 5 meter, the velocity of the boat also not too high when doing a rescue process, the engine rated power chosen is the engine with 15 HP. The engine is used with Mercury Marine Engine 15 HP 4 Stoke. The requirement of the engine is shown in Table 7.

Table 7: The requirement of the engine

\begin{tabular}{|l|l|}
\hline HP @ Prop: & 15 \\
\hline kW @ Prop: & 11.1 \\
\hline Max RPM (WOT) : & $4500-5500$ \\
\hline Cylinders: & 2 (in-line) \\
\hline Displacement (CID/cc) : & $19.7 / 323$ \\
\hline Bore \& Stroke (in) : & 2.32 x 2.32 \\
\hline Bore \& Stroke (mm) : & 59 x 59 \\
\hline Cooling System: & Water-cooled w/thermostat \\
\hline Ignition System: & CDI w/ electric spark advance \\
\hline Starting: & Manual or electric \\
\hline Gear Ratio: & $2.00: 1$ \\
\hline Gear Shift & F-N-R \\
\hline Steering: & Tiller or remote \\
\hline Alternator Amp: & 6 (manual)/10 (electric) \\
\hline Alternator Watt: & 76 (manual)/126 (electric) \\
\hline Trim Positions: & 5 \\
\hline Shallow Water Drive: & Standard \\
\hline Exhaust System: & Through prop \\
\hline Lubrication System: & Wet sump \\
\hline Recommended Oil: & Mercury 4-Stroke Outboard Oil \\
\hline Oil Capacity: & 1.0 L/1.1 Qt. \\
\hline Fuel Induction System: & 2 -valve single overhead cam \\
\hline Remote Fuel Tank: & Standard \\
\hline Remote Fuel Tank (US Gal) : & 3.2 \\
\hline Remote Fuel Tank (L) : & 12 \\
\hline Shaft Length (inches) : & $15 / 20$ \\
\hline Shaft Length (mm) : & $381 / 508$ \\
\hline Dry Weight (lbs.) : & 111 \\
\hline Dry Weight (kg.) : & 50 \\
\hline Operator Warning System: & Low oil pressure \\
\hline Available Propellers: & Standard equipment \\
\hline CARB Star Rating: & 2 \\
\hline Warranty: & 3 years \\
\hline & \\
\hline
\end{tabular}

Since this boat will be used in 3 different modes, the amount of DWT will be calculated on the different mode as well. This calculation will be shown below:

\section{Rescue Condition}

In this condition, it is assumed that boat will be evacuating the victim:

$$
\begin{aligned}
\text { a. Wfo } & \\
\text { Wfo } & =80 \% \times \text { BHP x } 0.17 \times \text { days } \\
\text { Wfo } & =80 \% \times 15 \times 0.17 \times 1 / 8 \\
& =0.255 \mathrm{~kg} \\
& =0.51 \mathrm{~kg}
\end{aligned}
$$

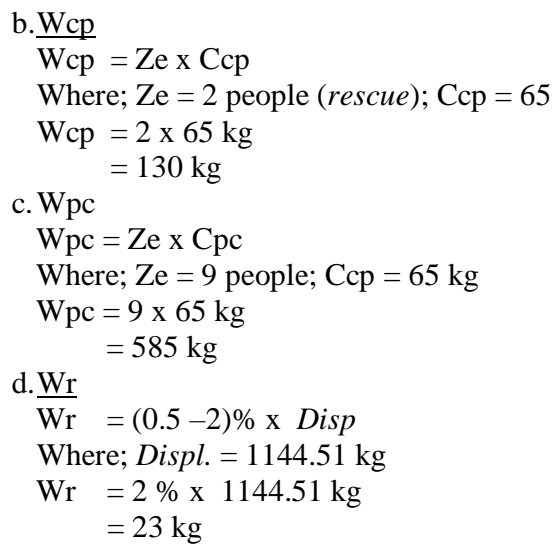

e. Weight of equipment

$\mathrm{W}$. equipment $=\mathrm{W}$. Life Jacket $+\mathrm{W}$. First aid + W. paddle + W. power machine + W. Fire extinguisher

$\mathrm{W}$. Life jacket $=($ Crew + Victim $) \times \mathrm{W}$ Life jacket $=11 \times 2 \mathrm{~kg}$ $=22 \mathrm{~kg}$

W. First Aid Kid $=$ Amount. $\mathrm{x}$ W First aid

$$
=9 \times 3 \mathrm{~kg}
$$$$
=27 \mathrm{~kg}
$$

$\mathrm{W}$. paddle $=$ Amount $\mathrm{x} \mathrm{W}$ paddle

$$
=2 \times 5 \mathrm{~kg}
$$$$
=10 \mathrm{~kg}
$$

$\mathrm{W}$. power machine $=$ Amount. $\mathrm{x}$ W.Engine

$$
\begin{aligned}
& =1 \times 50 \mathrm{~kg} \\
& =50 \mathrm{~kg}
\end{aligned}
$$

W. Fire extinguisher $=$ Amount. $\mathrm{x}$ W. Fire extinguisher

$$
\begin{aligned}
& =1 \times 5 \mathrm{~kg} \\
& =5 \mathrm{~kg}
\end{aligned}
$$

$\mathrm{W}$ equipment $\quad=22 \mathrm{~kg}+27 \mathrm{~kg}+10 \mathrm{~kg}+50 \mathrm{~kg}+5 \mathrm{~kg}$

$$
=114 \mathrm{~kg}
$$

$\mathrm{DWT}=\mathrm{Wfo}+\mathrm{Wcp}+\mathrm{Wpc}+\mathrm{Wr}+\mathrm{W}$ equipment $+\mathrm{W}$ lader $=0.51 \mathrm{~kg}+130 \mathrm{~kg}+585 \mathrm{~kg}+23 \mathrm{~kg}+114 \mathrm{~kg}+7 \mathrm{~kg}$ $=848 \mathrm{~kg}$.

DWT in Rescue Condition $=848 \mathrm{~kg}$

\section{Supply Condition}

In this condition, it is assumed that boat will be distributing the help, first aid and another supply:

a. Wfo

Wfo $=80 \% \times$ BHP $\times 0.17 \times$ days

Wfo $=80 \% \times 15 \times 0.17 \times 1 / 8$ $=0.255 \mathrm{~kg}$ $=0.51 \mathrm{~kg}$

b. Wcp

$\mathrm{Wcp}=\mathrm{Ze} \times \mathrm{Ccp}$

Where; $\mathrm{Ze}=3$ people (rescue); $\mathrm{Ccp}=65 \mathrm{~kg}$

Wcp $=3 \times 65 \mathrm{~kg}$

$$
=195 \mathrm{~kg}
$$

c. $\underline{\mathrm{Wr}}$

$\overline{\mathrm{Wr}}=(0.5-2) \% \times$ Displ.

Where; Displ. (planned $)=1144.51 \mathrm{~kg}$

$\mathrm{Wr}=2 \% \times 1144.51 \mathrm{~kg}$

$=23 \mathrm{~kg}$ 
Wheras:

$\operatorname{DWT}($ planned $)=836.51 \mathrm{~kg}$

$\mathrm{DWT}($ planned $)=\mathrm{Wfo}+\mathrm{Wcp}+\mathrm{Wr}$

+ Wpo (food, first aid, etc)

$$
\begin{aligned}
\text { Wpo } & =\mathrm{DWT}-(\mathrm{Wfo}+\mathrm{Wcp}+\mathrm{Wr}) \\
& =836.51-(0.51+195+23) \\
& =618 \mathrm{~kg}
\end{aligned}
$$

DWT in Supply Condition $=618 \mathrm{~kg}$

\section{Fire Fighting Condition}

In this condition, it is assumed that boat will be used as fire fighting vehicle:

$$
\begin{aligned}
& \text { a. Wfo } \\
& \mathrm{W} . \mathrm{Fo}=80 \% \times \text { BHP } \times 0.17 \times \text { days } \\
& \mathrm{W} . \mathrm{Fo}=80 \% \times 15 \times 0.17 \times 1 / 8 \\
& =0.255 \mathrm{~kg} \\
& =0.51 \mathrm{~kg} \\
& =195 \mathrm{~kg} \\
& \overline{\mathrm{Wr}}=(0.5-2) \% \times \text { Disp } \\
& \text { Where; Displ. } \text { (planned })=1144.51 \mathrm{~kg} \\
& \mathrm{Wr}=2 \% \times 1144.51 \mathrm{~kg} \\
& =23 \mathrm{~kg} \\
& =1 \times 94 \mathrm{~kg} \\
& =94 \mathrm{~kg} \\
& \text { W.Fire Extinguisher }=\text { Amount. } \mathrm{x} \text { Fire Extinguisher } \\
& =1 \times 5 \mathrm{~kg} \\
& =5 \mathrm{~kg} \\
& =0.51 \mathrm{~kg}+195 \mathrm{~kg}+23 \mathrm{~kg}+94 \mathrm{~kg}+5 \mathrm{~kg}=317.5 \mathrm{~kg}
\end{aligned}
$$

\subsection{DESIGN ARRANGEMENT}

\subsection{General Arrangement}

For the General arrangement of the rescue boat, the boat will have an efficient and aesthetic accommodation room. This is shown in Figure 3. The rescue boat will also have rescue platform and quick riling system. On the platform ladder is as shown in Figure 4. There are hinges that will connect the edge of the platform with the boat surface. When the boat is operating, this ladder could be spin with the hinges as its center. When it is not used, the ladder will be put on the topside of the boat. On a certain condition, this platform could be released. When it is released and the edge of the boat where the previous platform is connected could be installed with the row so the boat could be connected and created a new function. This is used as a bridge from the boat. This function is called as the quick riling system where the boat makes a unity to create pathways. This condition could be seen in Figure 6.

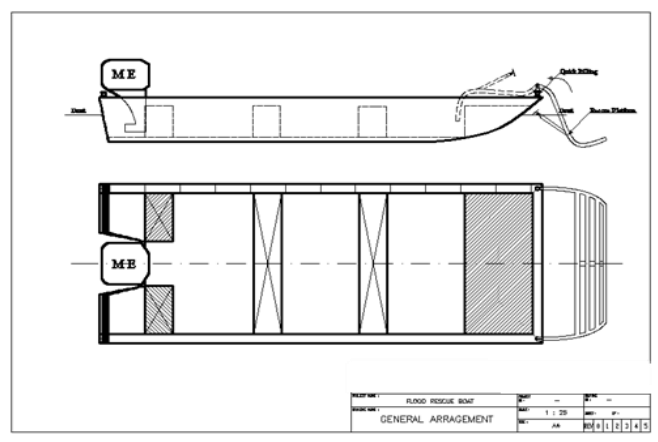

Figure 3: General arrangement of the rescue boat

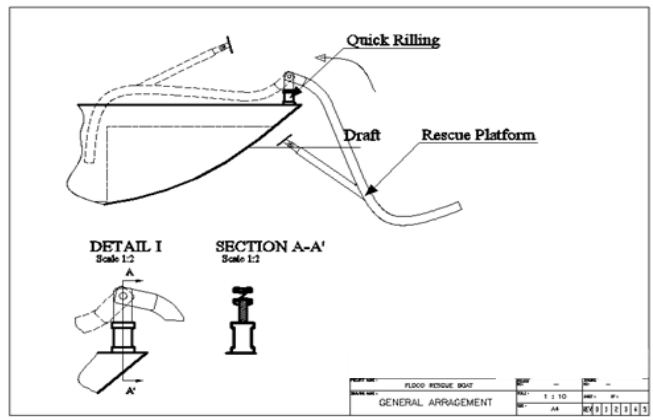

Figure 4: Design of the platform (Side View)

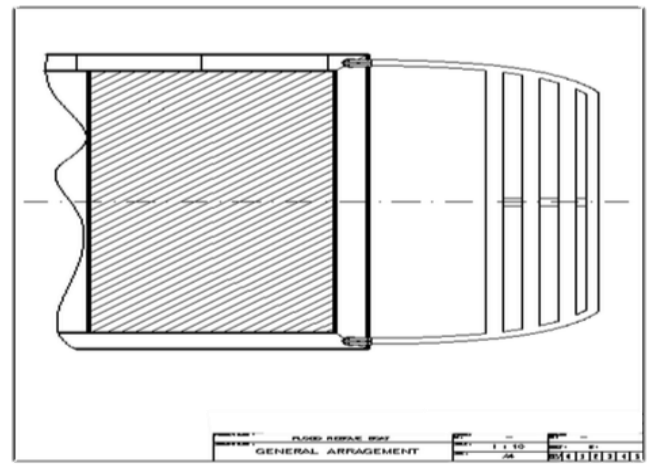

Figure 5: Design of the platform (Top View)

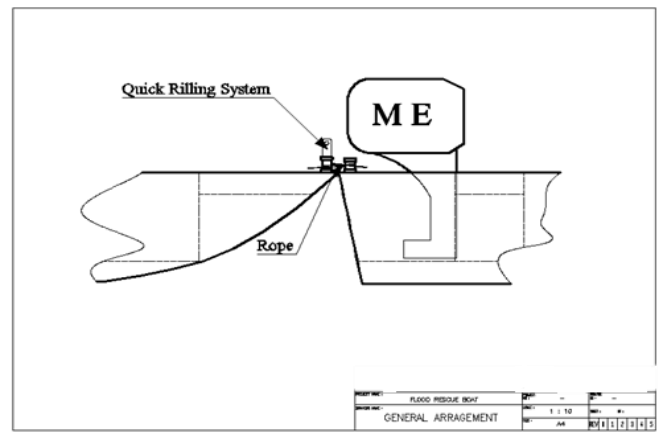

Figure 6: Design of the quick riling system 


\subsection{Construction Calculation}

1. Material Propertis

$0.2 \%$ proof strees (minimum ) $125 \mathrm{~N} / \mathrm{mm}^{2}$

Tensile Strength (minimum ) $260 \mathrm{~N} / \mathrm{mm}^{2}$

Modulus of elasticity $69 \times 10^{3} \mathrm{~N} / \mathrm{mm}^{2}$

2. Frame Spacing

$a=(350+5 . L) \mathrm{mm}$

Where:

$$
\begin{aligned}
\mathrm{L} & =\text { length of construction }(\mathrm{m}) \\
\mathrm{L} & =4.65 \mathrm{~m} \\
\mathrm{a} & =(350+5.4 .65) \mathrm{mm} \\
& =373.25 \mathrm{~mm}, \text { used } \mathrm{a}=380 \mathrm{~mm}
\end{aligned}
$$

3. Hull Plate

$$
\begin{gathered}
\text { a. Rasio } \\
A=\frac{V}{\sqrt{L W L}} \\
\mathrm{~V}=9.5 \mathrm{knots}
\end{gathered}
$$$$
\mathrm{LWL}=4.5 \mathrm{~m}
$$$$
\mathrm{A}=\frac{8}{\sqrt{4.5}}
$$$$
=3.7 \text {, used } \mathrm{a}=3.6
$$

L.R ; tb $=3.5 \mathrm{~mm} ; \mathrm{ts}=3 \mathrm{~mm}$

b. Thickness of bottom plate (minimum)

$$
\begin{aligned}
t b_{(\min )} & =(0.075 . L+2.75) \geq 3.5 \mathrm{~mm} \\
& =(0.075 .4 .5+2.75) \\
& =3.08 \mathrm{~mm}
\end{aligned}
$$

c. Thickness of side plate (minimum)

$$
\begin{aligned}
t_{s_{(\min )}} & =(0.06 . L+2.5) \geq 3 \mathrm{~mm} \\
& =(0.06 .4 .5+2.5) \\
& =2.77 \mathrm{~mm}
\end{aligned}
$$

d. Keel plate thickness and breadth of keel plate

$$
\begin{aligned}
\operatorname{tk}_{(\min )} & =3.5 \mathrm{~mm} \\
\mathrm{~b} & =400 \mathrm{~mm} \\
\text { or } & \\
t k_{(\min )} & =(0.125 . L+2.75) \geq t b \\
& =(0.125 .4 .5+2.75) \\
& =3.31 \mathrm{~mm} \\
\text { Breadth } & =(10 . L+340) \mathrm{mm} \\
& =(10.4 .5+340) \\
& =385 \mathrm{~mm}
\end{aligned}
$$

4. Internal Hull Stucture

Finding the thickness of plate inside the engine, ased on frame spacing, height of the engine and its ratio.

$\mathrm{D}_{\text {motor }}=1.25 \mathrm{~m}$

$$
\mathrm{a} \quad=380 \mathrm{~mm} \text { (Frame spacing) }
$$

$$
\begin{aligned}
A & =\frac{V}{\sqrt{L W L}}=3.6 \\
\mathrm{tb} & =5.2 \mathrm{~mm} \\
\mathrm{ts} & =2.2 \mathrm{~mm}
\end{aligned}
$$

5. Shell Framing Transverse

Bottom,

$$
\begin{aligned}
Z_{B F} & =4.74 \mathrm{sl}^{2} F_{B F}(102.5 \mathrm{~h}+7.7 \mathrm{~L}) 10^{-3} \mathrm{~cm}^{3} \\
I & =1.85 \mathrm{lZ}_{B F} \mathrm{~cm}^{4} \\
\text { Side, } & \\
Z_{S F} & =4.74 \mathrm{sl}^{2} F_{S F}(102.5 \mathrm{~h}+5.08 \mathrm{~L}+14.6) 10^{-3} \mathrm{~cm}^{3} \\
I & =1.85 \mathrm{l} Z_{S F} \mathrm{~cm}^{4} \\
A & =\frac{V}{\sqrt{L W L}}=3.6 \text { for } L<24 \mathrm{~m}
\end{aligned}
$$

$$
\begin{aligned}
& F_{V B F}=(0.837 . \sqrt{ } A-0.648) \times(2.61-0.246 \sqrt{ } L) \text { for } L<30 \mathrm{~m} \\
& =(0.837 . \sqrt{3} .6-0.648) \times(2.61-0.246 \sqrt{4} .8) \\
& =0.94 \times 2.071 \\
& =1.947 \\
& F_{V S F}=(0.724 . \sqrt{ } A-0.433) \times(1.91-0.17 \sqrt{ } L) \text { for } L<30 \mathrm{~m} \\
& =(0.724 . \sqrt{3} .6-0.433) \times(1.91-0.17 \sqrt{4} .5) \\
& =0.94 \times 1.537 \\
& =1.44 \\
& Y \quad=0.83 \text { for flat bars } \\
& \Delta \quad=\text { Displacement }=1144.51 \\
& \Delta k=0.125\left(L^{2}-15.8\right) \\
& =0.125\left((4.5)^{2}-15.8\right) \\
& =0.556 \text { ton } \\
& f_{\Delta S}=\frac{0.5 \Delta}{\sqrt{\Delta k}}+0.5 \\
& =\frac{0.5 \cdot 1.364}{\sqrt{0.556}}+0.5 \\
& =1.415 \\
& F_{\Delta S}=f_{\Delta S}\left[(0.074-0.39 . \sqrt{ } A) x\left(\frac{\Delta k-\Delta}{0.3 \Delta k}\right)+1.0\right] \\
& =4.22 \\
& F_{B F}=\left(F_{V B F} \times F_{A S} x y\right) \geq 1.0 \text { for motor boat } \\
& =(1.947 \times 4.22 \times 0.83) \\
& =6.819 \\
& F_{S F}=\left(F_{V S F} \times F_{A S} x_{Y}\right) \geq 1.0 \text { for motor boat } \\
& =(1.44 \times 4.22 \times 0.83) \\
& =5.044 \\
& Z_{B F}=4.74 s l^{2} F_{B F}(102.5 \mathrm{~h}+7.7 \mathrm{~L}) 10^{-3} \mathrm{~cm}^{3} \\
& =4.740 .38(1.6)^{2} 6.819(102.50 .25+7.74 .5) 10^{-3} \\
& =1895.2 \times 10 .{ }^{-3} \mathrm{~cm}^{3} \\
& =1.8 \mathrm{~cm}^{3} \\
& I \quad=1.85 \mathrm{l} \mathrm{Z}_{B F} \mathrm{~cm}^{4} \\
& =1.851 .61 .8 \\
& =5.328 \mathrm{~cm}^{4} \\
& Z_{S F}=4.74 \mathrm{sl}^{2} F_{S F}(102.5 \mathrm{~h}+5.08 \mathrm{~L}+14.6) 10^{-3} \mathrm{~cm}^{3} \\
& =4.740 .38(0.4)^{2} 5.044(102.50 .25+5.084 .5+14.6) 10^{-3} \mathrm{~cm}^{3} \\
& =91702.9 \times 10^{-5} \mathrm{~cm}^{3} \\
& =0.917 \mathrm{~cm}^{3} \\
& I \quad=1.85 \mathrm{lZ}_{\mathrm{SF}} \mathrm{cm}^{4} \\
& =1.85 \cdot 0.4 \cdot 0.917 \\
& =0.678 \mathrm{~cm}^{4}
\end{aligned}
$$

Table 8: Weight of contstruction

\begin{tabular}{|l|l|c|c|c|c|}
\hline \hline No & \multicolumn{1}{|c|}{ Areas } & $\begin{array}{c}\text { area } \\
\left(\mathrm{m}^{2}\right.\end{array}$ & $\begin{array}{c}\text { Thickness } \\
(\mathrm{mm})\end{array}$ & $\begin{array}{c}\text { SG } \\
\left(\mathrm{kg} / \mathrm{m}^{3}\right)\end{array}$ & $\begin{array}{c}\text { Weight } \\
(\mathrm{kg})\end{array}$ \\
\hline \hline 1 & Bottom plate & 8.738 & 3.0 & 2700 & 70.778 \\
\hline 2 & Side plate & 4.350 & 3.0 & 2700 & 35.235 \\
\hline 3 & Floor plate & 5.004 & 3.5 & 2700 & 47.288 \\
\hline 4 & Floor plate in E/R & 1.021 & 5.0 & 2700 & 13.784 \\
\hline 5 & Transom & 1.193 & 3.0 & 2700 & 9.663 \\
\hline 6 & Profile in bottom side & 0.776 & 5.0 & 2700 & 10.469 \\
\hline 7 & Profile in side side & 0.400 & 5.0 & 2700 & 5.395 \\
\hline 8 & Chairs for the passenger & 4.862 & 3.0 & 2700 & 39.382 \\
\hline 9 & Crew chair & 1.430 & 3.0 & 2700 & 11.583 \\
\hline 10 & Front chair & 2.040 & 3.0 & 2700 & 16.524 \\
\hline 11 & Straith side $(\mathrm{p} / \mathrm{s})$ & 0.338 & 3.0 & 2700 & 5.473 \\
\hline 12 & Bottom Straith & 0.378 & 3.0 & 2700 & 18.347 \\
\hline \multicolumn{7}{|l}{} & & $\sum=$ & 283.921 \\
\cline { 4 - 6 } & & &
\end{tabular}


For the final stability of the rescue boat, it will be analyzed based on a several condition. It is shown on Table. 9.

Table. 9: Analysis based on a several condition of the rescue boat

\begin{tabular}{|l|c|c|c|c|c|c|c|c|}
\hline $\begin{array}{l}\text { Condition } \\
\text { of the } \\
\text { cargoes }\end{array}$ & $\begin{array}{c}\text { KB } \\
(\mathbf{m})\end{array}$ & $\begin{array}{c}\text { KG } \\
(\mathbf{m})\end{array}$ & $\begin{array}{c}\text { BMt } \\
(\mathbf{m})\end{array}$ & $\begin{array}{c}\text { BML } \\
(\mathbf{m})\end{array}$ & $\begin{array}{c}\text { KMt } \\
(\mathbf{m})\end{array}$ & $\begin{array}{c}\text { KML } \\
(\mathbf{m})\end{array}$ & $\begin{array}{c}\text { GMt } \\
(\mathbf{m})\end{array}$ & $\begin{array}{c}\text { GML } \\
(\mathbf{m})\end{array}$ \\
\hline $25 \%$ & 0.051 & 0.275 & 2.931 & 13.539 & 2.981 & 13.590 & 2.706 & 13.315 \\
$50 \%$ & 0.067 & 0.334 & 2.240 & 10.737 & 2.307 & 10.804 & 1.973 & 10.470 \\
$75 \%$ & 0.075 & 0.368 & 1.889 & 10.031 & 1.965 & 10.106 & 1.597 & 9.738 \\
$100 \%$ & 0.089 & 0.390 & 1.655 & 9.633 & 1.744 & 9.722 & 1.655 & 9.633 \\
\hline $\begin{array}{l}3 \text { victim } \\
\text { on side }\end{array}$ & 0.052 & 0.377 & 2.458 & 12.145 & 2.509 & 12.197 & 2.143 & 11.831 \\
\hline $\begin{array}{l}6 \text { victim } \\
\text { on side }\end{array}$ & 0.065 & 0.404 & 2.035 & 10.974 & 2.100 & 11.039 & 1.704 & 10.643 \\
\hline Supply & 0.093 & 0.234 & 1.540 & 8.557 & 1.634 & 8.650 & 1.399 & 8.416 \\
\hline $\begin{array}{l}\text { Fire } \\
\text { Fighting }\end{array}$ & 0.054 & 0.304 & 2.613 & 12.986 & 2.667 & 13.040 & 2.636 & 12.986 \\
\hline
\end{tabular}

After all the data are obtained. The figure, drawing, design and arrangement will be shown on the figure 7-figure 14:

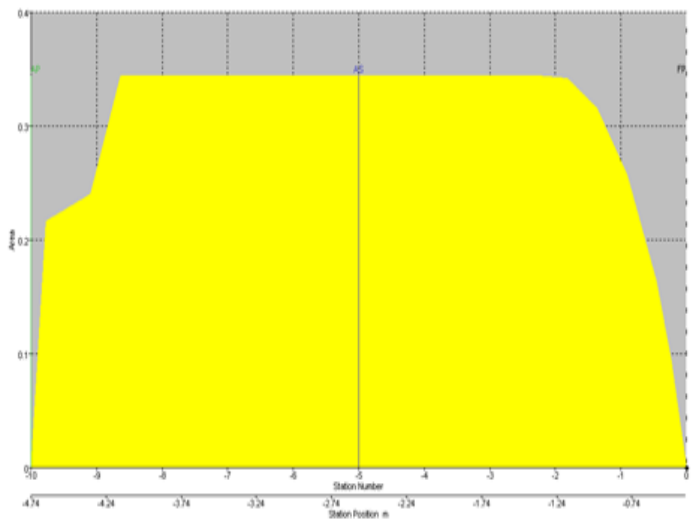

Figure 7: CSA Curve
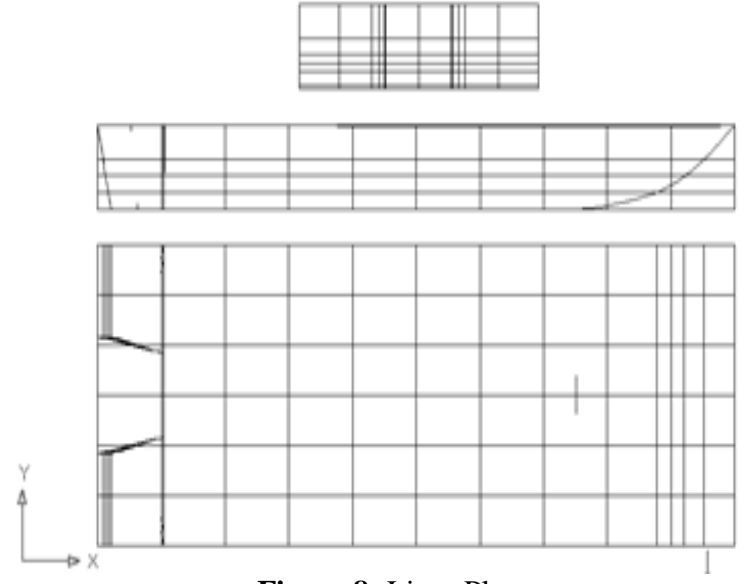

Figure 8: Lines Plan

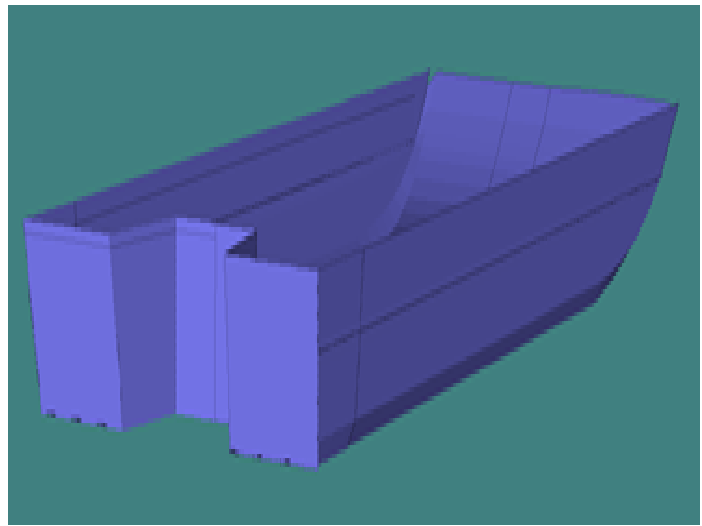

Figure 9: 3D Model

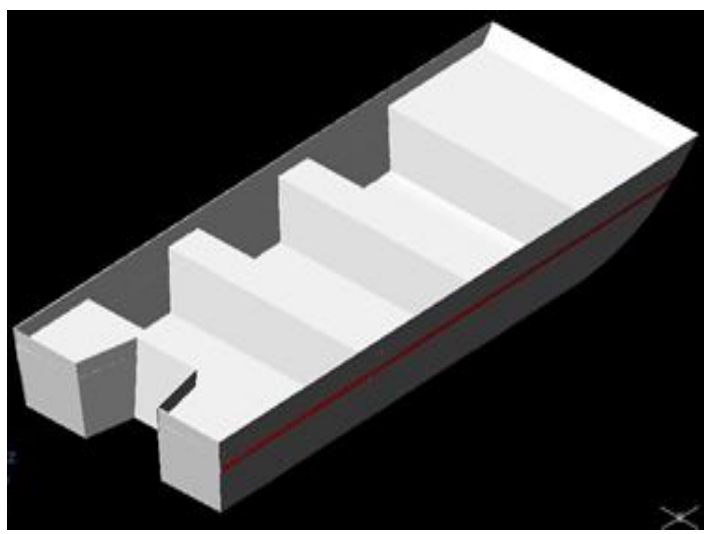

Figure 10: 3D Model

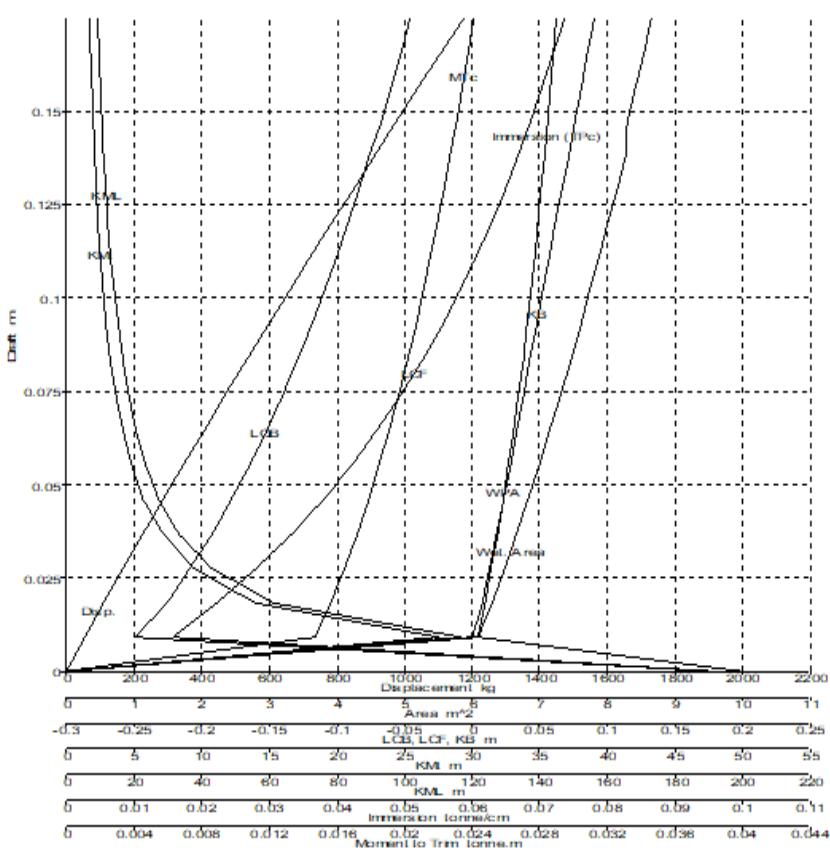

Figure 11: Hydrostatic in $25 \%$ Cargo 


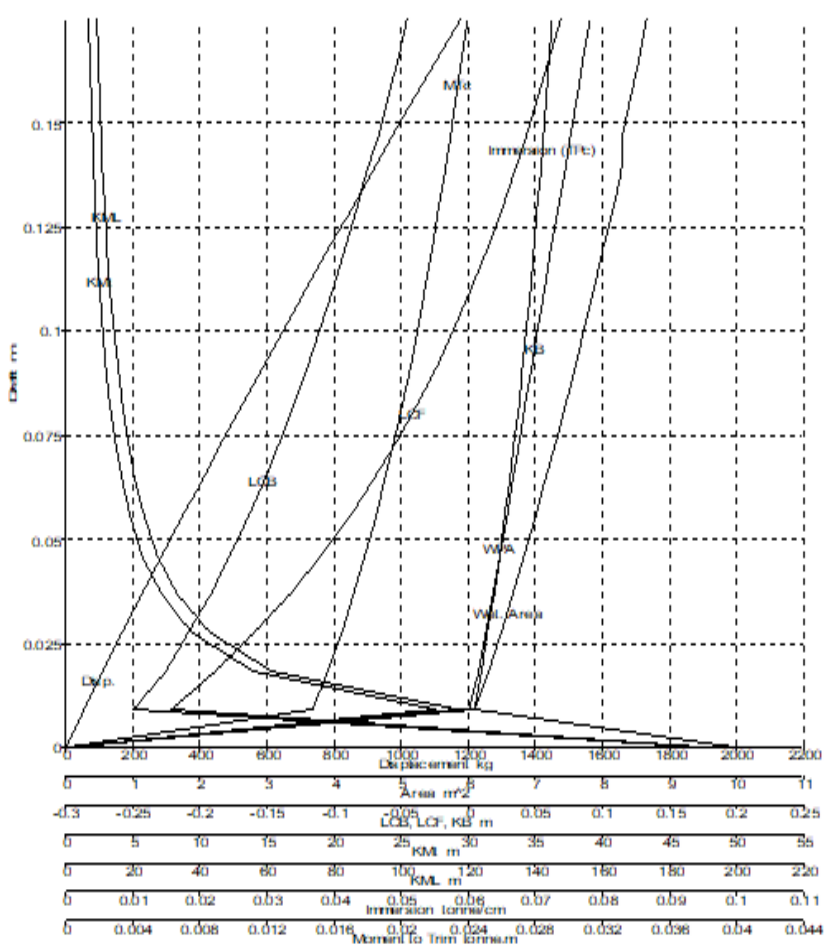

Figure 12: Hydrostatic in $50 \%$ Cargo

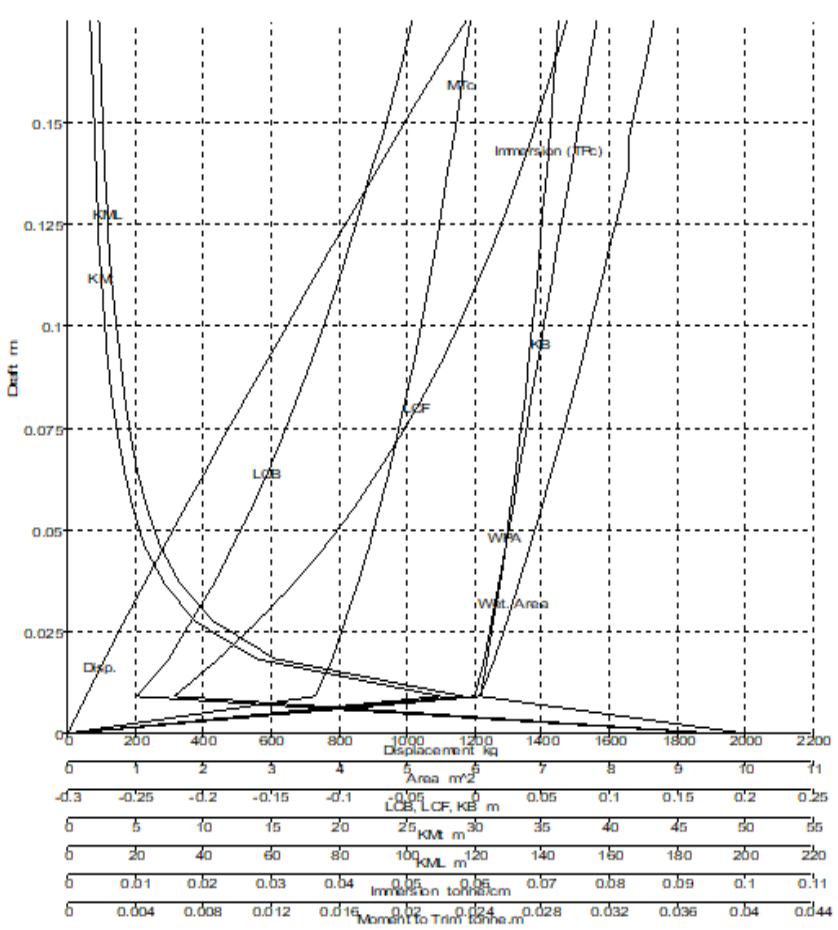

Figure 13: Hydrostatic in $100 \%$ Cargo

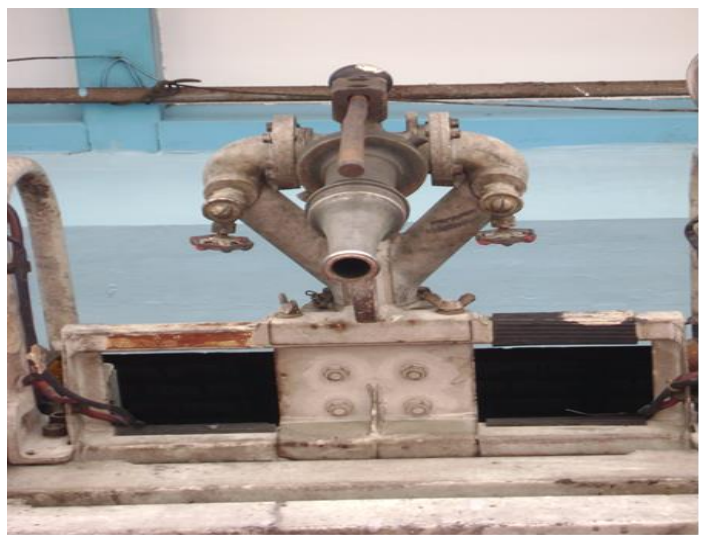

Figure 14: Installed Fire Monitor (radius $15-60^{\circ}$ )

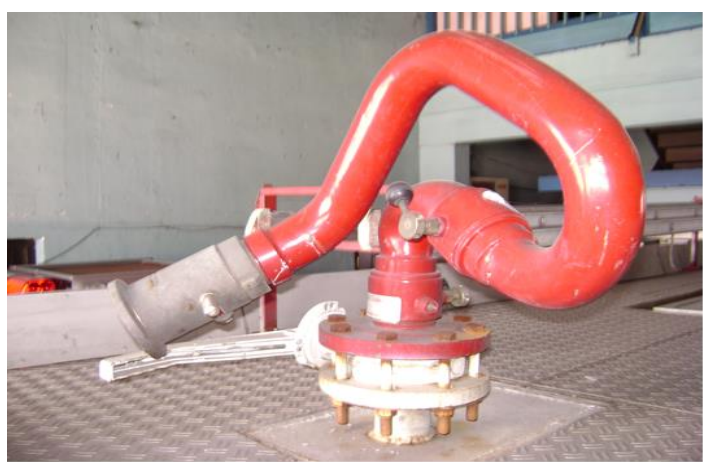

Figure 15: Installed Fire Monitor $\left(360^{\circ}\right)$

\subsection{CONCLUSION}

1. Based on the various condition and simulation, the principal dimension (fixed) that used is :

LOA (Lenght Over All) $\quad: 4.8 \mathrm{~m}$

$B$ (Breadth) $\quad: 1.8 \mathrm{~m}$

$d$ (draft) $\quad: 0.175 \mathrm{~m}$

$H$ (Height) $\quad: 0.5 \mathrm{~m}$

2. This boat have the value of good stability. It is based on the criteria from IMO regulation, which are :

- MG value is no less than $0.15 \mathrm{~m}$. MG is measure in various condition which is in empty cargo load, $25 \%, 50 \%, 75 \%$, and $100 \%$. It has the values of MG with: $57.84 \mathrm{~m}, 24.16 \mathrm{~m}$, $18.57 \mathrm{~m}, 15.20 \mathrm{~m}, 12.51 \mathrm{~m}$.

- The opening of a water-resistant vessel begins to touch water at an angle of $40^{\circ}$ or more, in this boat design is of value: $104.2^{\circ}, 73.7^{\circ}, 68.6^{\circ}, 64.6^{\circ}, 64.3^{\circ}$.

- The maximum arm occurs between $25^{\circ}-30^{\circ}$, at this boat design all maximum arms are at the condition of empty loads, $25 \%, 50 \%, 75 \%$, and $100 \%$ occur at an angle of $30 \mathrm{o}$.

- At a slope of $30 \mathrm{o}$ or more, the moment arm (GZ) is $0.2 \mathrm{~m}$ or more, at this boat design the moment arm values (GZ) are: $0.62 \mathrm{~m}, 0.44 \mathrm{~m}, 0.41 \mathrm{~m}, 0.39 \mathrm{~m}, 0.39 \mathrm{~m}$. 
- The area under the static stability curve at $0-30^{\circ}$ is greater than $0.055 \mathrm{~m}$. Rad, in this boat design the values are: 0.269 m. Rad, 0.168 m. Rad, 0.151 m. Rad, 0.138 m. Rad, 0.142 m. Rad.

- The area under the static stability curve at 0 - 40o is greater than $0.09 \mathrm{~m}$. Rad, in this boat design the values are: 0.373 m. Rad, 0.242 m. Rad, 0.220 m. Rad, 0.203 m. Rad, 0.207 m. Rad.

3. Based on the standard fire extinguisher pump at the Fire Department The pressure needed for the fire extinguishing process is 5-8 bar with the condition of the permanent building (Wall) for the resident condition. So the pressure chosen in the final assignment is the minimum pressure of 5 bars.

4. Based on the calculation of the height and pressure relationship obtained from the height of sprayed water of $50,985 \mathrm{~m}$ with a pressure of 5 bar and the pump power is 3.73 $\mathrm{kW}$ with a capacity of $656 \mathrm{LPM}$ (Liter Per Minute)

5. Dead Weight or Consumble;

a. Rescue condition $=848 \mathrm{~kg}$

b. Supplay condition with DWT planned $836.51 \mathrm{~kg}=$ could carry supply with maximum weight of $618 \mathrm{~kg}$

c. $\quad$ Fire Fighting condtion $=317.5 \mathrm{~kg}$

6. The profile used is type I with details:

Bottom frame planned $=30 \times 5$

Side frame planned $=30 \times 5$

Calculation of the weight of the construction obtained $284 \mathrm{~kg}$.

\section{REFERENCE}

1. D'Arcangelo A, (1969). Ship Design and Construction, SNAME, Jersey City.

2. Bai, Y. and Bai,Q. (2010).Subsea Engineering Handbook: Elsevier.

3. D'Arcangelo, A. (1969), Ship Design and Construction, SNAME, Jersey City. ITTC (2011), Recommended Procedures and Guidelines, Model Manufacture: Ship Models, ITTC 7.5-01 -01-01.

4. D.G.M. Watson. (1998). Practical Ship Design, Elsevier, Amsterdam.

5. George C Manning. (1956). The Theory and Technique of Ship Design, Massachusetts.

6. Li, Z. G (2010). Configuration of Submarine Pipeline for Deep water S-Lay Technique, The International Society of Offshore and Polar Engineers.

7. Palmer, A. C. and King, R. A. (2008). Subsea Pipeline Engineering: Pennwell Corporation.

8. Shao, B., Yan, X.et al. (2011). Reliability Analysis of Locally Thinned Submarine Pipelines in Cheng Dao Oil Field, Applied Mechanics and Materials Vols. 94-96, pp: 15271530.

9. Soegiono \& IGM Santosa (1990), Perencanaan Kapal, Fakultas Teknologi Kelautan ITS

10. Soemartojo, W.A. (2008), "Handout; Teori Bangunan Kapal", JTSP FTK ITS

11. Watson, D.G.M. (1998), Practical Ship Design, Elsevier, Amsterdam 